\title{
MINIMALLY INVASIVE SINGLE-DOOR PLATE LAMINOPLASTY WITH LATERAL MASS SCREW FIXATION FOR THE UNSTABLE SEGMENT. REPORT OF TWO CASES WITH LONG FOLLOW-UP
}

\author{
LAMINOPLASTIA EM PORTA ABERTA MINIMAMENTE INVASIVA COM FIXAÇÃO COM \\ PARAFUSOS DE MASSA LATERAL PARA O SEGMENTO INSTÁVEL. RELATO DE \\ DOIS CASOS COM ACOMPANHAMENTO PROLONGADO
}

\author{
LAMINOPLASTIAA EN PUERTA ABIERTA MÍNIMAMENTE INVASIVA Y FIJACIÓN CON \\ TORNILLO DE MASA LATERAL PARA O SEGMENTO INESTABLE. REPORTE DE \\ DOS CASOS CON SEGUIMIENTO A LARGO PLAZO
}

\author{
Sergio Soriano-Solís', Javier Quillo-Olvera², Manuel Rodríguez-Garcíaª , Héctor Antonio Soriano Solís ${ }^{3}$, José-Antonio Soriano-Sánchez ${ }^{1}$ \\ 1. Centro Médico ABC, Santa Fe, Cuajimalpa de Morelos, México. \\ 2. The Brain and Spine Care Center, Hospital Star Medica Querétaro, San Pablo, Santiago de Querétaro, Querétaro, Mexico. \\ 3. Hospital Central Nacional PEMEX Norte, Del. Azcapotzalco, San Antonio, Mexico.
}

\begin{abstract}
Objective: To report two cases of multilevel cervical spondylotic myelopathy with monosegmental instability, in which we performed a minimally invasive microsurgical transmuscular approach with tubular retractors to create a single-door plate laminoplasty combined with fixation of the unstable segment with lateral mass screws. Methods: The surgical procedures were performed by the senior author. In both patients, the follow-up was performed using the Oswestry Disability Index (ODI), the Visual Analogue Scale for neck and radicular pain (radVAS, neckVAS), the Neck Disability Index (NDI) and the Short Form 36 (SF-36), in the preoperative (preop) and postoperative (postop) periods, and at $1,3,6,12,18$ and 24 months. A radiological evaluation also was performed, which included AP, lateral and flexion-extension films at 6, 12 and 24 months and CT-scan at 12 months. Results: Case 1 - preop ODI: 40\%, 24 months postop ODI: 4\%; preop radVAS: 7, 24 months radVAS: 0; preop neckVAS: 8, postop 24 months neckVAS: 0; preopNDI: 43\%, 24 months PostopNDI: 8\%; SF-36 - preop Physical Functioning (PF): 40, preop Vitality (VT): 40, preop Emotional role functioning (RE): 33.3, Bodily pain (BP): 51, General Health (GH): 57, Social Functioning (SF): 75; postop PF: 95, VT: 95, RE: 100, BP: 74, GH: 87, SF: 100. Case 2 - preopODI: 46\%, 24 months postopODI: 10\%; preop radVAS: 7, 24m radVAS: 0; preop neckVAS: 9, postop 24 months neckVAS: 0; preopNDI: 56\%, 24 months PostopNDI: 15\%; SF-36 - preop PF: 39, VT: 45, RE: 33.3, BP: 50, GH: 49, SF: 70; postop PF: 90, VT: 100, RE: 100, BP: 82, GH: 87, SF: 100. No complications, cervical instability or signs of failed surgery were found trough and at final follow-up at 24 months. We found significant clinical improvement in both patients. Conclusions: Minimally invasive cervical laminoplasty combined with lateral mass screw fixation for the unstable segment is a useful technique in cases with multilevel cervical spondylotic myelopathy associated with monosegmental instability. Additional comparative studies are needed to establish its efficacy.
\end{abstract}

Keywords: Cervical vertebrae; Laminectomy; Spinal cord diseases; Spondylosis; Minimally invasive surgical procedures.

\section{RESUMO}

Objetivo: Relatar dois casos de mielopatia espondilótica cervical em múltiplos níveis com instabilidade de um só segmento, nos quais realizamos uma microcirurgia minimamente invasiva por via transmuscular com retratores tubulares para criar uma laminoplastia em porta aberta com fixação do segmento instável com parafusos de massa lateral. Métodos: Os procedimentos cirúrgicos foram realizados pelo autor principal. Em ambos os pacientes, o acompanhamento foi realizado usando Índice de Incapacidade de Oswestry (ODI), Escala Visual Analógica para dor cervical e radicular (EVAc e EVArad), Índice de Incapacidade Relacionada ao Pescoço (NDI) e o Short Form 36 (SF-36) nos períodos pré-operatório (pré-op) e pós-operatório (pós-op) e em 1, 3, 6, 9, 12, 18 e 24 meses. Realizou-se também a avaliação radiológica, que incluiu vistas AP, laterais e de flexão-extensão aos 6, 12 e 24 meses e TC aos 12 meses. Resultados: Caso 1 - ODI pré-op: 40\%, ODI 24 meses pós-op: 4\%; pré-op EVArad: 7, EVArad 4 meses: 0; EVAc pré-op: 8, EVAc pós-op 24 meses: 0; NDI pré-op: 43\%, NDI pós-op 24 meses: 8\%; SF-36 - capacidade funcional (CF) pré-op: 40, vitalidade (VT) pré-op: 40, aspectos emocionais (AE) pré-op: 33,3, dor (D): 51, estado geral da saúde (ES): 57, aspectos sociais (AS): 75; CF : 95, VT: 95, AE: 100, D: 74, ES: 87, AS: 100 pós-op. Caso 2 - ODI pré-op: 46\%, ODI 24 meses pós-op: 10\%; EVArad pré-op : 7, EVArad 24 meses: 0; EVAc pré-op: 9, EVAc 24 meses pós-op: 0; NDI pré-op: 56\%, NDI 24 meses pós-op: 15\%; SF-36 pré-op: CF: 39, VT: 45, AE: 33,3, D: 50, ES: 49, AS: 70; CF: 90, VT: 100, AE: 100, D: 82, ES: 87, AS: 100 pós-op. Não houve complicações, instabilidade cervical ou sinais de falha da cirurgia durante o acompanhamento de 24 meses. Ambos os pacientes apresentaram melhoras significativas. Conclusões: A laminoplastia cervical minimamente invasiva combinada com fixação de parafuso de massa lateral do segmento instável é uma técnica útil nos casos com mielopatia espondilótica cenvical em vários níveis associada à instabilidade de um só segmento. É necessário realizar estudos comparativos adicionais para estabelecer a eficácia do procedimento.

Descritores: Vértebras cervicais; Laminectomia; Doenças da medula espinal; Espondilose; Procedimentos cirúrgicos minimamente invasivos.

Study conducted at the Centro Médico ABC Santa Fe, Mexico City, Mexico

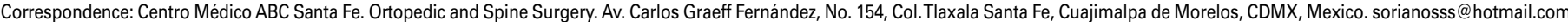




\section{RESUMEN}

Objetivo: Relatar dos casos de mielopatía espondilótica cervical en múltiples niveles con inestabilidad de un solo segmento, en los que realizamos una microcirugía mínimamente invasiva por vía transmuscular con retractores tubulares para crear una laminoplastia en puerta abierta con fijación del segmento inestable con tornillos de masa lateral. Métodos: Los procedimientos quirúrgicos fueron realizados por el autor principal. En ambos pacientes, el seguimiento fue realizado usando Índice de Discapacidad de Oswestry (ODI), Escala Visual Analógica para dolor en el cuello y radicular (EVAc y EVArad), Índice de Discapacidad Cervical (NDI) y el Short Form 36 (SF-36) en los períodos preoperatorio (preop) y postoperatorio (posop) y en 1, 3, 6, 9, 12, 18 y 24 meses. Se realizó también la evaluación radiológica, que incluyó proyecciones AP, laterales y de flexión-extensión a los 6, 12 y 24 meses y TC a los 12 meses. Resultados: Caso 1 - ODI preop: 40\%, ODI 24 meses posop: 4\%; EVArad preop: 7, EVArad 4 meses: 0; EVAc preop: 8, EVAc posop 24 meses: 0; NDI preop: 43\%, NDI posop 24 meses: 8\%; SF-36 - función física (FF) preop: 40, vitalidad (VT) preop: 40, rol emocional (RE) preop: 33,3, dolor corporal (DC): 51, salud general (SG): 57, función social (FS): 75; FF: 95, VT: 95, RE: 100, DC: 74, SG: 87, FS: 100 posop. Caso 2 - ODI preop: 46\%, ODI 24 meses posop: 10\%; EVArad preop: 7 , EVArad 24 meses: 0; EVAc preop: 9, EVAc 24 meses posop: 0; NDI preop: 56\%, NDI 24 meses posop: 15\%; SF-36 preop: FF: 39, VT: 45, RE: 33,3, D: 50, SG: 49, FS: 70 preop; FF: 90, VT 100, RE 100, DC 82, SG: 87, FS: 100 posop. No hubo complicaciones, inestabilidad cervical o signos de falla de la cirugía durante el seguimiento de 24 meses. Ambos pacientes presentaron mejoras significativas. Conclusiones: La laminoplastia cervical mínimamente invasiva combinada con fijación de tornillo de masa lateral del segmento inestable es una técnica útil en los casos con mielopatía espondilótica cervical en múltiples niveles asociada a la inestabilidad de un solo segmento. Es necesario realizar estudios comparativos adicionales para establecer la eficacia del procedimiento.

Descriptores: Vértebras cervicales; Laminectomía; Enfermedades de la médula espinal; Espondilosis; Procedimientos quirúrgicos mínimamente invasivos.

\section{INTRODUCTION}

Cervical laminoplasty (CL) was developed in the 1970s in Japan ${ }^{1}$ as an alternative to nonfusion laminectomy for patients with cervical spondylotic myelopathy in which associated complications included: spinal deformity, instability, "laminectomy membrane" compression and late neurological deterioration. Since then, many modified techniques have been described for $\mathrm{CL}$, with varying results. ${ }^{2}$ Titanium miniplate laminoplasty has the advantage of immediate stabilization of the elevated laminae, and has proven efficacy. ${ }^{3-6,2,7,8}$ Minimally invasive spine surgery (MISS) techniques have demonstrated, in the past decade, critical advantages over traditional surgery and are commonly used in cervical spine surgery. MISS approaches for laminoplasty have recently been described as attempts to preserve the posterior anatomy of the cervical spine (muscles, ligaments and joints) and avoid the postoperative complications associated with it. ${ }^{9-16}$ Likewise, MISS techniques for cervical spine decompression and stabilization have been described elsewhere. ${ }^{17}$ The purpose of the study is to show the results of single-door plate laminoplasty and lateral mass screw fixation using a microsurgical transmuscular approach with the use tubular retractors in two patients with multilevel cervical spondylotic myelopathy and gross monosegmental instability.

\section{Case \#1}

A 71 year-old female housewife with 1 year evolution of neck pain irradiated to the middle and annular finger of her right hand accompanied by weakness and clumsiness. Also with worsening of the pain at night and intermittent tingling in the fingers of her right hand. Over the last 2 months, similar symptoms affected the left hand, but were less severe. The pain had worsened her quality of life, with difficulty applying make-up, dressing, and opening doors, among other activities of daily living

Physical examination showed walking instability due to weakness of her right pelvic limb, kyphotic cervical posture, pain on palpation of the C4 trough C7 interspinous spaces, and tenderness on palpation of sternocleidomastoid, trapezius and paravertebral muscles in the interscapular region. Paresis of the deltoid, biceps and triceps $3 / 5$ and left sided weakness of the wrist flexors and opponens pollicis muscle $4 / 5$ was identified, according to the Medical Research Council (MRC) scale. Sensitivity was found with non-dermatomal alterations. The osteotendinous reflexes (OTRs) were positive for hyporreflexia in the thoracic limbs and hyperreflexia in the lower limbs. A positive Spurling's sign was found bilaterally. Plantar reflex and other pyramidal signs were negative.

Plain AP, lateral and dynamic $X$-ray films (Figure 1) and magnetic resonance imaging (MRI) (Figure 2) were obtained showing: multiple

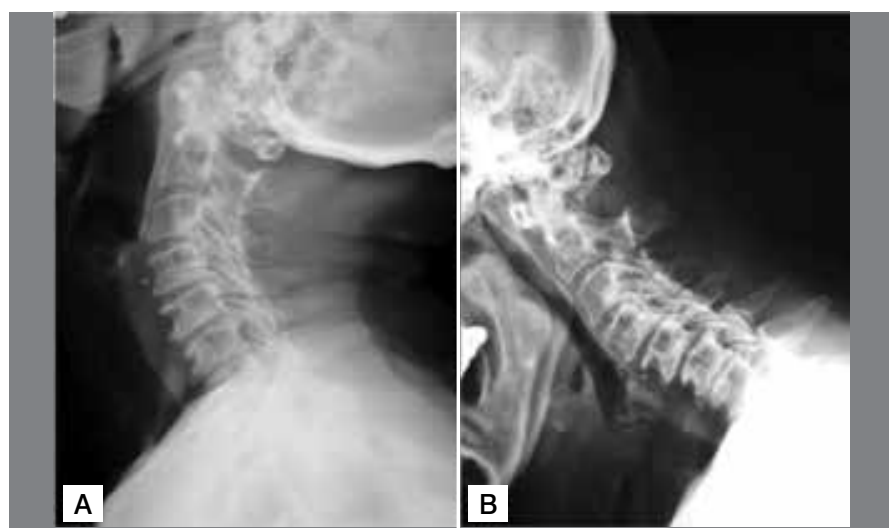

Figure 1. Neutral (A) and flexion (B) plain films showing C5-C6 anterior subluxation and advanced spondylotic changes with posterior osteophytes complexes from $\mathrm{C} 3$ to $\mathrm{C} 7$

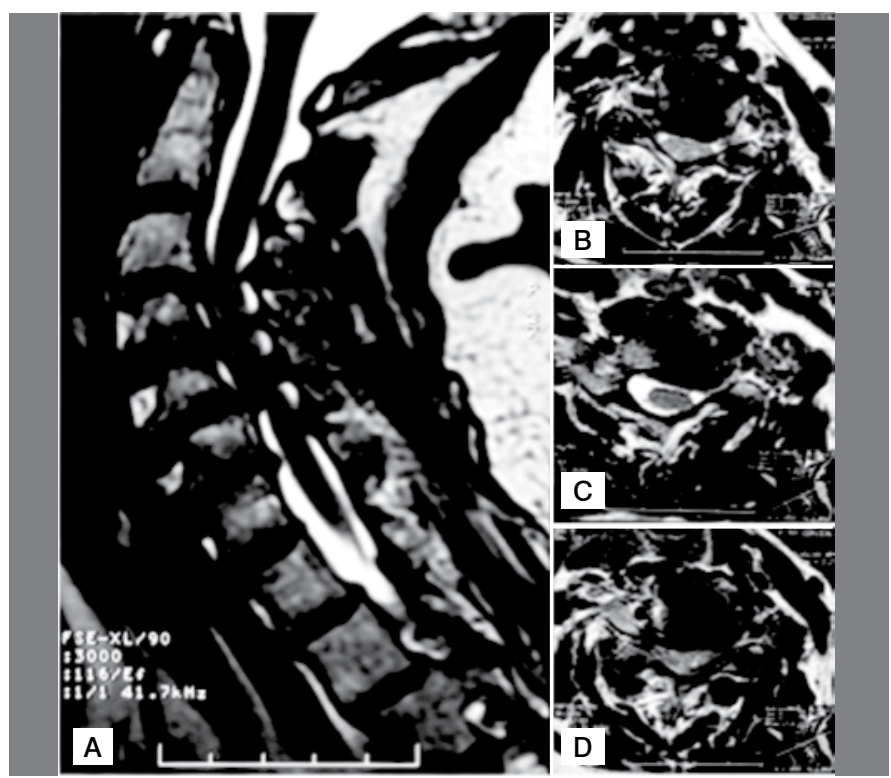

Figure 2. (A) Magnetic resonance imaging (MRI) showing important canal stenosis with a more important posterior compression vector (ligamentum flavum) $\mathrm{C} 3$ to $\mathrm{C} 7$ in the lateral view. Axial cuts at the center of the disc show disc bulging contacting but not displacing of the spinal cord in C3-C4 (B), no contact in C4-C5 (C) and slight, asymmetric displacement at C5-C6 (D). 
degenerative disc changes from $\mathrm{C} 3$ to $\mathrm{C} 7$, left foraminal stenosis from $\mathrm{C} 4$ to $\mathrm{C} 7$ and right foraminal stenosis in C5-C6. Anterior and posterior spinal cord compression predominantly in C5-C6. Anterior subluxation in C5-C6.

\section{Case \#2}

A 73 year-old housewife with a 6-month history of numbness in the left arm irradiating to the lateral surface of the forearm, and the thumb and index finger of her left hand. One month after the start of the symptoms, weakness of distal predominance added, with clumsiness and difficulty in activities of daily living. She also referred affected sensitivity in the palm of her right hand, difficulty for walking and heaviness sensation in both legs.

The physical exam revealed spastic and unstable walking, limitation for neck movements especially for extension. Pain to palpation of interspinous spaces from C3 to C6, as well as paravertebral muscles. Tenderness to palpation of both trapezius muscles. Muscle paresis in 4/5 for left deltoid, biceps, triceps and interosseous muscles bilaterally, $3 / 5$ for wrist extensors and opponens pollicis with bilateral involvement according to MRC scale. OTRs registered hyporreflexia of left tricipital and hyperreflexia of patellar and Achilles reflex. Positive Tromner and Hoffman reflexes. Positive Babinski sign. Hypoesthesia of left C4 dermatome also was found.

$\mathrm{AP}$, lateral, dynamic plain films and MRI demonstrate degenerative disc changes in levels C3 to C7 with osteophyte-disc complexes, collapse and fusion of the disc space at level C5-C6, with compromise of the spinal cord. Also, an anterior subluxation of $\mathrm{C} 4-\mathrm{C} 5$ was found. A lateral plain $x$-ray images demonstrating anterior subluxation is shown in Figure 3.

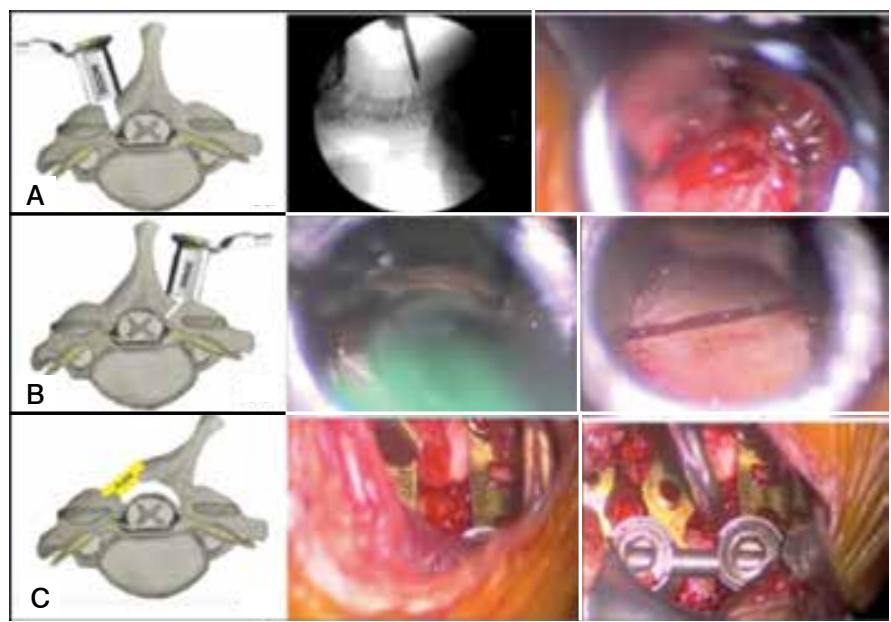

Figure 3. Surgical technique summary. Door side (A), hinge side (B) and plating $(\mathrm{C})$ are shown

\section{MATERIALS AND METHODS}

Both patients agreed to be enrolled in the present study, which was approved by the institutional committee. Patients were admitted on the day of the surgery. Both had an ASA II risk for surgery. The surgical procedures were performed by the senior author. The follow-up was performed using the Oswestry Disability Index (ODI), the Visual Analogue Scale for neck and radicular pain (radVAS, neckVAS), the Neck Disability Index (NDI) and the Short Form 36 (SF-36) in the preoperative (preop) and postoperative (postop) periods at: 1, 3, 6, 12,18 and 24 months. A radiological evaluation also was performed, including AP, lateral and flexion-extension x-ray images at 6, 12 and 24 months and a CT-scan at 12 months.

\section{Surgical Technique}

The patient was placed in the prone position, with the head supported by a Mayfield clamp in slight flexion and neutral rotation. An AP fluoroscopic image was obtained and the skin was marked in the facet-laminae junction at the target levels. A $2 \mathrm{~cm}$ vertical incision was made on each side of the midline. Fat tissue was dissected until the trapezius muscle fibers were visualized. The trapezius muscle fibers were split by blunt dissection to identify the splenius cervicis muscle fibers, which were divided, carefully following their orientation. The final muscle plane is the semispinalis capitis and colli muscle, which again, was bluntly dissected. Tubular retractors (MetRx I System, Medtronic ${ }^{\circledR}$ ) were then placed in the laminofacet junction under fluoroscopic guidance. Hemostasis and the subsequent steps were completed under microscopic view (OPMI Pentero 900, Zeiss $\left.{ }^{\circledR}\right)$. The muscle fibers attached to the laminae were dissected. According to the Roy-Camille and Saillant technique ${ }^{18}$ lateral mass screws were inserted, under fluoroscopic guidance, for the unstable segment. A gutter was created in the junction between the articular process and the laminae with a high-speed burr, just medial to the pedicles, without harming the facet. The gutter was deepened until the laminae was thinned around $2 \mathrm{~mm}$ and was then completed on the dominant side with Kerrison rongeurs. The hinge side was then approached, and the laminae thinned. Finally a green stick fracture was created in the hinge side, and the posterior arch shifted to the hinge side. Any fibrous adhesions between the dural sac and the laminae should be removed carefully. Pulsation of the dural sac should be confirmed. A mini plate fixation system was added to maintain spinal canal widening, and fixed to the facet and laminae with mini screws. Careful hemostasis was conducted, and the wound was closed by layers. Figure 3 demonstrate the three critical steps.

\section{RESULTS}

Blood loss was $66 \mathrm{~mL}$ for Case 1 and $75 \mathrm{~mL}$ for Case 2. No complications occurred during the surgical procedures. Mean operative time was 275 minutes for Case 1 and 320 minutes for Case 2. No complications, cervical instability or signs of failed surgery were found in the perioperative period and through the final follow-up at 24 months in both patients. Figure 4 demonstrates the comparison between preoperative and postoperative plain $x$-ray images at final follow-up. Table 1 shows the summary of the rad VAS, neckVAS, ODI and NDI for both patients in the preoperative and final postoperative periods. Figure 5 summarize the SF-36 results by components.

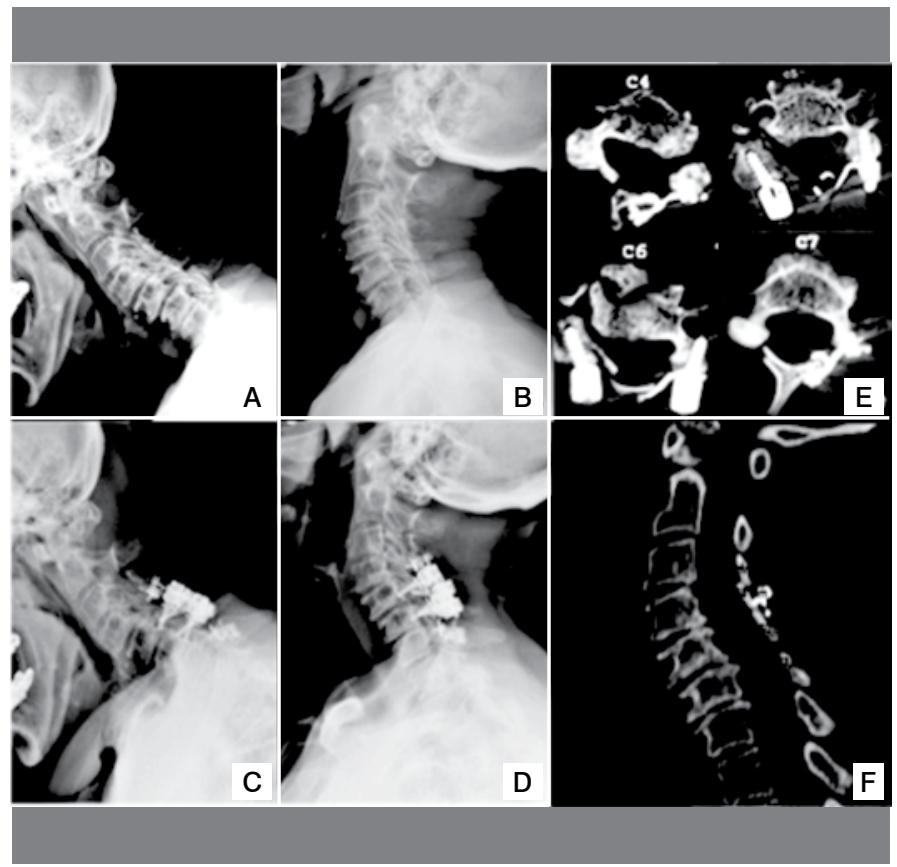

Figure 4. Construct behavior in dynamic $X$-rays at 2 year follow-up ( $C$ and $D$ ) versus preoperative dynamic plain films (A and B). Immediate postoperative CT-scan shows spinal canal widening in axial $(E)$ and sagittal views $(F)$. 
Table 1. Clinical Follow-up.

\begin{tabular}{c|c|c|c|c|c|c|c|c}
\hline Case 1 & & & & & & & \\
\hline & Pre & $\mathbf{1 m}$ & $\mathbf{3 m}$ & $\mathbf{6 m}$ & $\mathbf{9 m}$ & $\mathbf{1 2 m}$ & $\mathbf{1 8 m}$ & $\mathbf{2 4 m}$ \\
\hline $\mathrm{NDI}^{+}$ & $54 \%$ & $20 \%$ & $16 \%$ & $17 \%$ & $14 \%$ & $12 \%$ & $12 \%$ & $12 \%$ \\
\hline ODI $^{*}$ & $40 \%$ & $14 \%$ & $6 \%$ & $6 \%$ & $6 \%$ & $6 \%$ & $6 \%$ \\
\hline radVAS $^{++}$ & 7 & 2 & 1 & 0 & 0 & 0 & 0 \\
\hline neckVAS & 8 & 4 & 1 & 0 & 0 & 0 & 0 \\
\hline Case 2 & & & & & & & 0 \\
\hline NDI & $56 \%$ & $35 \%$ & $30 \%$ & $30 \%$ & $30 \%$ & $30 \%$ & $22 \%$ & $10 \%$ \\
\hline ODI & $46 \%$ & $20 \%$ & $12 \%$ & $12 \%$ & $10 \%$ & $10 \%$ & $10 \%$ & $10 \%$ \\
\hline radVAS & 7 & 3 & 2 & 0 & 0 & 0 & 0 \\
\hline neckVAS & 9 & 5 & 3 & 3 & 3 & 2 & 0 \\
\hline
\end{tabular}

+NDI - Neck Disability Index; *ODI - Oswestry Disability Index; ++radVAS - Radicular Visual Analogue Scale for pain; **neckVAS - Neck Visual Analogue Scale for pain.

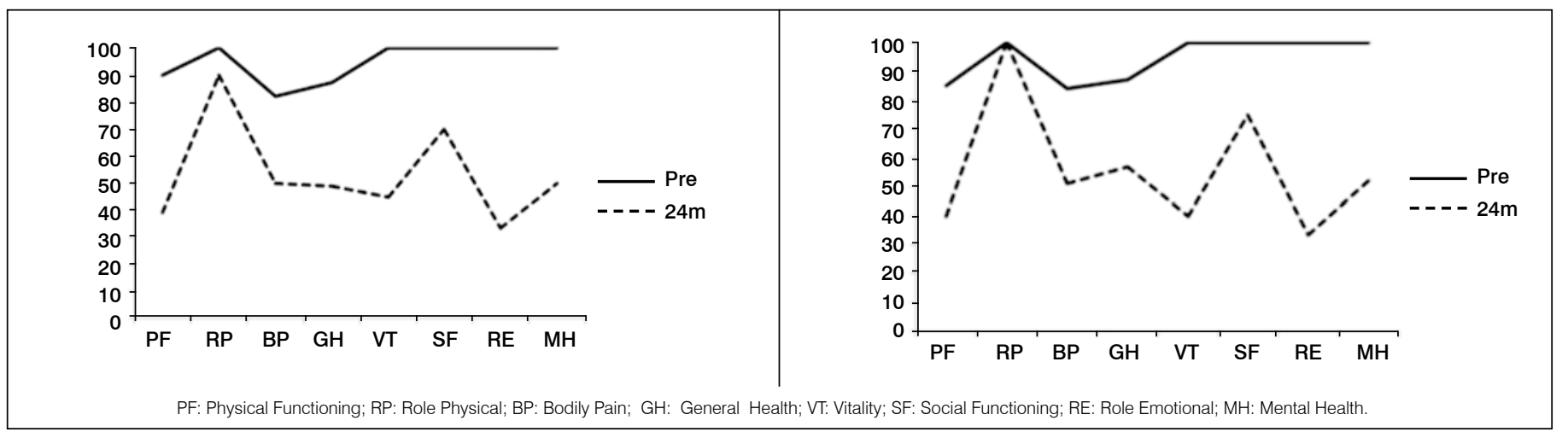

Figure 5. Case 1 and 2 Short-Form 36 Chart showing improvement in all components at final follow-up.

\section{DISCUSSION}

MCSM is not an uncommon presentation of cervical degenerative disease. Surgical treatment of MCSM remains controversial and challenging. Laminoplasty is a common procedure, and has proven to be a safe and viable option compared to laminectomy. ${ }^{5}$ Also, MISS is a growing field in spine surgery, offering better results in the early postoperative period and offering the same results in the long term as open surgery in many cases, and all for spinal regions. ${ }^{19}$

Many variations to the original laminoplasty technique have been published since its origins. ${ }^{20}$ Plate laminoplasty was first described by Frank and colleagues ${ }^{10}$ in 1994 , offering a solution to maintain spinal canal diameter widening.
In the present study, we show the clinical outcomes of two patients with MCSM managed with minimally invasive single-door plate cervical laminoplasty and lateral mass screw fixation for the unstable segment. To our knowledge there are no previous studies in the literature on minimally invasive cervical laminoplasty and lateral mass screw fixation for the unstable segment with tubular retractors employing a transmuscular approach.

Although this study only includes two patients, we demonstrate a clear improvement in functional outcomes at 24 months (ODI, radVAS, neckVAS, SF-36 and NDI). Additional randomized, comparative studies are required to prove its efficacy.

All authors declare no potential conflict of interest related to this article.

CONTRIBUTION OF THE AUTHORS: SSS: Bibliography search, Image edition, Discussion, Proofreader it's better, Final edition and corrections. JQO Statistical Analysis. SSS, JQO, MRG Surgical team. MRG Images edition, HASS Data collection, HASS Bibliography search. JASS Main Surgeon, Reviewer.

\section{REFERENCES}

1. Hirabayashi K, Satomi K. Operative procedure and results of expansive open-door laminoplasty. Spine (Phila Pa 1976). 1988:13(7):870-6

2. Ratliff JK, Cooper PR. Cervical laminoplasty: a critical review. J Neurosurg. 2003;98 (3 Suppl):230-8.

3. Fornari M, Luccarelli G, Giombini S, Chiapparini L. Artificial lamina-assisted laminoplasty performed in seven cases. J Neurosurg. 1999;91(1 Suppl):43-9.

4. Frank $\mathrm{E}, \mathrm{TL}$ Keenen. A technique for cervical laminoplasty using mini plates. Br J Neurosurg. 1994:8(2):197-9.

5. Lao L, Zhong G, Li X, Qian L, Liu Z. Laminoplasty versus laminectomy for multi-level cervical spondylotic myelopathy: a systematic review of the literature. J Orthop Surg Res. 2013:8:45

6. O'Brien M, Peterson D, Casey ATH, Crockard HA. A novel technique for laminoplasty augmentation of spinal canal area using titanium miniplate stabilization. A computarized morphometric analysis. Spine (Phila Pa 1976). 1996;21(4):474-83.

7. Shaffrey $\mathrm{Cl}$, Wiggins GC, Piccirilli CB, Young JN, Lovell LR. Modified open-door laminoplasty for treatment of neurological deficits in younger patients with congenital spinal stenosis: analysis of clinical and radiographic data. J Neurosurg. 1999.90(2 Suppl):170-7.

8. Stendel R, Krischek B, Pietila TA. Biodegradable implants in neurosurgery. Acta Neurochir (Wien). 2001;143(3):237-43

9. Abdullah KG, Yamashita T, Steinmetz MP, Lubelski D, Wang JC, Benzel EC, et al. Open-door cervical laminoplasty with preservation of posterior structures. Global Spine J. 2012:2(1):15-20.

10. Benglis DM, Guest JD, Wang MY. Clinical feasibility of minimally invasive cervical laminoplasty. Neurosurg Focus. 2008;25(2):E3

11. Kato M, Nakamura $H$, Konishi S, Dohzono S, Toyoda H, Fukushima W, et al. Effect of preserving paraspinal muscles on postoperative axial pain in the selective cervical laminoplasty. Spine (Phila Pa 1976). 2008;33(14):E455-9

12. ShiraishiT. A new technique for exposure of the cervical spine laminae. Technical note. $J$ Neurosurg. 2002;96(1 Suppl):122-6.

13. Shiraishi T, Kato M, Yato Y, Ueda S, Aoyama R, Yamane J, et al. new tecnhiques for exposure of posterior cervical spine through intermuscular planes and their surgical application. Spine (Phila Pa 1976). 2012;37(5):E286-96.

14. Shiraishi T, Yato Y, Yoshida $H$, Abe T, Ikegami T. New double-door laminoplasty procedures to preserve the muscular attachments to the spinous processes inclunding the axis. Eur J Orthop Surg Traumatol. 2002;12(4):175-80.

15. Wang MY, Green BA, Coscarella E, Baskaya MK, Levi AD, Guest JD. minimally invasive cervical expansile laminoplasty: an initial cadaveric study. Neurosurgery. 2003:52(2):370-3.

16. Wang M. Minimally Invasive surgery in the Cervical Spine: recent advances. Curr Opin Orthop 2007:18:259-62

17. Mikhael MM, Celestre PC, Wolf CF, MrozTE, Wang JC. Minimally invasive cervical spine foraminotomy and lateral mass screw placement. Spine (Phila Pa 1976). 2012 Mar 1;37(5):E318-22.

18. Roy-Camille R, Saillant G. Chirurgie du rachis cervical: Luxation- fracture des articulaires. Nouv Presse Med. 1972:1(37):2484-5.

19. Skovrlj B, Qureshi SA. Minimally invasive cervical spine surgery. J Neurosurg Sci. 2016 Oct 27. [Epub ahead of print] PubMed PMID: 27787486.

20. Roselli R, Pompucci A, Formica F, Restuccia D, Di Lazzaro V, Valeriani M, et al. Open-door laminoplasty for cervical stenotic myelopathy: surgical technique and neurophysiological monitoring. J Neurosurg. 2000:92(1 Suppl):38-43. 